\title{
THE ROOTS OF INDISCIPLINE IN CONTEMPORARY GHANAIAN SOCIETY - A SOCIOLOGICAL PERSPECTIVE
}

\author{
K. Wireko-Brobby \\ Department of Sociology and Social Work, \\ Kwame Nkrumah University of Science \& Technology, Kumasi, Ghana
}

\begin{abstract}
The spate of indiscipline in contemporary Ghanaian society is quite alarming and this certainly is a source of concern for many law abiding Ghanaians. As a social problem, indiscipline manifests itself in several forms and represents all that is a violation of healthy and decent existence in society. The manifestation of indiscipline in the Ghanaian society has been the outcome of external and internal factors. The former has to do with the nature of external interventions, influences and the international economic order and the latter problems of mismanagement as a result of failed political leadership, characterized by greed and ignorance.
\end{abstract}

Keywords: Society, Orderliness, Major Institutions, Structural Contradictions and Indiscipline.

\section{INTRODUCTION}

Broadly defined, society is a collection of active human beings interacting with one another in a given geographical area. Orderliness is implied in the concept of society, hence, one of the main concerns of sociologists is to explain how social life is possible. Parsons (1951) argues that a certain degree of order and stability are essential for the survival of social systems. From his analysis that has come to represent the functionalist perspective, Parson claims that, for the smooth running of any society, four challenges referred to as functional pre-requisites must be solved.

The first of these is the need, for survival pur- poses, to meet the physical requirements of its members. Food and shelter are the minimum requirements. Their provision usually involves some system of production and distribution. The term Economy describes this institutional structural arrangement of society.

The second requirement for survival is the need to ensure that these requirements reach the society. The term Polity, that is Goal Attainment is used to describe this structural arrangements of society. Goal Attainment is necessary because the resources of society are always scarce or in short supply. It is the attainment of this goal that brings politics into this picture. Political arrangements 
are involved because to determine the priorities of scarce resources, it is necessary to wield 'State Power'. And usually, there are two main ways of attaining this end: one is through the ballot box; i.e. the legitimate way, the other is through the barrel of the gun, the illegitimate way.

The third functional prerequisite is that of Kinship that is the web of Social network in the institutions of marriage and family. This important institution is saddled with the problems and responsibilities of procreation and socialization of the young. It is against this background that one can appreciate the important role of the family as helping in developing stable personalities and commitment to societal values. The final one consists of Community Organizations, that is, educational institutions, mass media and communications. In fact, community organizations share the functions of integrating the various elements and institutions. Ideally, they can create, demonstrate and reinforce social values.

When the above four (4) functional prerequisites are in perfect equilibrium, problems of a pathological nature, that is, Dysfunctional activities are very minimal. According to Parsons, the key processes for attaining this theoretical state of equilibrium are 'Socialization' and 'Social Control'. From this perspective, improper Socialization and any lack of Social Control are manifestations of indiscipline that affect the foundations of society. Ghana as a country is beset with problems of indiscipline. Gross indiscipline has pervaded all the four (4) functional pre-requisites of Ghanaian Society. The modest aim of this paper is an attempt at demonstrating that indiscipline as a social problem is the effects of the structural sources of contradictions that have become inherent in contemporary Ghanaian Society.

\section{Ghana and the problem of indiscipline}

The country we currently call Ghana was until 1957 known as the Gold Coast. It was colonized by the British in 1902, won its independence in
1957 and achieved Republican status in 1960. Geographically, it is located on the west coast of Africa. Ghana as a state in transition, (Assimeng 1999 ) is beset with problems of Indiscipline.

The concept of indiscipline implies a deviation from a normal path that is committed to a special set of values, standard expectations and behaviour patterns. Indiscipline thus includes but is not limited to any blatant and wanton disregard for the laws and cherished values of the land like: Unorthodox and illegal acquisition of wealth; e.g. 'Get-Rich-Quick' attitude Indiscriminate felling of trees through illegal chain saw operations; Building in water courses, resulting in floods; Indiscriminate dumping of waste, Reckless driving on our roads resulting in fatal accidents; Rampant mob action including instant justice, Increasing police brutality, Sycophancy and graft; Bribery and Corruption and our poor attitude towards work, to mention only a few.

Another disturbing form of indiscipline is the inaction of those who should act. Regrettably, most of our law enforcement agencies and various oversight bodies who are to ensure Ghanaians do the right things are indifferent.

\section{Causes of indiscipline}

The causes of indiscipline are directly traceable to Five (5) separable but related factors. These are:

1. External Factors i.e. the Colonial Heritage

2. Internal Contradictions between Institutions

3. Socio-Economic Pressures and Anomic Conditions

4. Family Problem - Failure of Home Life

5. Failed Political Leadership

External factors, influences and implications

The British Government took over the administration of Ghana, then the Gold Coast in 1902. With the seizure of 'State Power' the British introduced massive fundamental changes. Nukunya (2005) argues that 'Even if changes were taking place before 1902, the changes following this period were significantly different from those preceding it'.

118 Journal of Science and Technology, Vol. 28, No. 2, August, 2008 
These changes included formal classroom education, monetized Economy and Christianity among others. Indeed, on the surface, one cannot but admire the impressive array of these changes. Ironically, their management and implementation have had the unintended consequences that have contributed to a large extent, to the spate of indiscipline in the country.

The quest to colonize was not an accident. One cannot appreciate colonialism without reference to Industrialization; the Berlin Conference and conditions outside Africa itself. Both radicals and conservative scholars are agreed on this point. In his brilliant analysis of the struggle against world imperialism, Nkrumah (1962) who became the first President of the Republic of Ghana adequately offers some of the major reasons in his famous book,

'Towards Colonial Freedom.'

'The purpose of founding colonies was mainly to secure raw materials and to safeguard the measures for securing such raw materials the following policies were indirectly put into action: i) to make the colonies non-manufacturing dependencies; (ii) to prevent the colonial subjects acquiring the knowledge of modern means and techniques for developing their own industries; (iii) to make colonial 'subjects' simple producers of raw materials through cheap labour; (iv) to prohibit the colonies from trading with other nations except through the 'mother country'.

Historically, it has been documented that the colonialist did not institute measures that favoured the colonies. Writing on the policies of the Colonial powers, Oliver et al (1996) stress that:

'Once Africa had been divided between them, the European governments lost much of their earlier interest in the continent. There were few parts of Africa, which were expected to produce immediate wealth. The European nations had partitioned Africa mainly in order to ensure that the would not be excluded from regions, which might prove valuable in the future. Possession was what mattered to them, not development'.

Major policies on education, health care systems, housing and transportation were profoundly unsuitable and inappropriate for solving the basic needs and problems of the country. In the case of education, it was geared towards providing clerks and other Junior-level personnel essential in keeping the colonial bureaucracy and commercial activity running. Commenting on colonial policies, Nkrumah (1962) in a similar vein writes

'The conference of Berlin (1890), the Treaty of Versailles, the Covenant of the League of $\mathrm{Na}$ tions, and the Trusteeship System of U.N.O., each and every one of these pacts contained provisions 'to protect and guard' colonial peoples. These provisions, however, were adopted to camouflage the economic philosophy of colonial powers so as to exploit with impunity. The material development - railways, roads, bridges, schools, hospitals - that are noticeable in the colonies have been merely accidental adjuncts to facilitate economic exploitation of the colonies. The colonial powers build hospitals because if the health of the colonial subject is not taken care of it will not only jeopardize their own health but will diminish the productive power of the colonial labourer. They build schools in order to satisfy the demand for clerical activities and occupations for foreign commercial and mercantile concerns. The roads they build lead only to the mining and plantation centres. In short, any humanitarian act of any colonial power towards the 'ward' is merely to enhance its primary objective: economic exploitation'.

These policies have already had their negative impact on the lives of Ghanaian. Some of the unintended consequences have been the emergence of a socially defective environment resulting from contradictions and internal mismanagement.

Internal contradictions between institutions

There is lack of fit between the major institutions. 


\section{Contradictions between the economy and the} educational system

One of the major responsibilities of the educational system (i.e. formal education) is to prepare and provide the necessary workers for the prevailing system of production and the level of technology (Economy) which society requires. In a superficial way this may mean teaching the kind of subjects in schools which pupils will need to know for their future jobs. The source of tension is that the content of most subjects taught in school are unrelated to the world of work. This is a genuine problem in Ghana and has been a source of concern to many. Assimeng echoes the sentiments of many when he laments that:

'A nation which is basically agricultural should have had a system of education in which agriculture as a teaching subject would have a deserved priority in educational curricula. But again the various stresses have been at the verbal level only, and the bias and prejudices of administrators entrusted with the implementation of radical policies on education merely became evident.'

In fact, the relationship is more subtle than this. The school system, in addition, unfortunately acts as a kind of 'Sorting out Agency' or a clearing house for employment. This is done largely through the workings of its examination system. From this angle the picture in Ghana is very pathetic. According to Addae-Mensah et al. (1973)

'Some of the major problems inherent in our present educational system is that where as $70 \%$ of the total number of school going age receive some form of primary education, only about $10 \%$ of them are able to proceed beyond this level, with 5\% of them gaining access to secondary education, and the remaining being distributed among technical, commercial, vocational or post-primary teacher training.'

A series of unpleasant repercussions flow from this. Unemployability results. Indeed, this lapse is perhaps the most unfortunate major unintended consequence of our educational system. Assimeng puts the picture succinctly when he writes:

'Most of the causes of unemployment in this country may be appropriately sought in the structure of the country's system of formal education and its historical connection. It has been mentioned on several occasions, almost ad nauseam that the pattern of the educational system is in need of a radical reorientation'.

The disturbing aspect is that the affected groups are described and unfortunately labelled as 'failures' and 'dropouts'. Consequently, they feel humiliated, rejected and alienated. Lack of counselling in our schools accelerates and in fact worsens the process of frustration already in motion. This is with regard to those who have managed to go through the system. For this category the system becomes very gloomy and oppressive. They look at their elders who are jobless including those who have completed the S.S.S. Those in the group become even further insecure when they see unemployed graduates and they are coming in their numbers! The results? Most of the people in this category become absent-minded in class and in turn, misbehave and add to the problem of indiscipline.

\section{Contradictions between the educational system and the family}

For teachers, misbehaviour creates problems. The sad truth is that the teacher has also got his own personal problems. There is the desire to make ends meet at a time when the take-home pay is incapable of taking him home. For most teachers it is no longer a question of Hand to mouth, it has become Hand to Chest! Most teachers are not content to be happy with the notion that their reward is in Heaven. The reaction and attitude of the public and the contemptuous attitude shown to the teachers by people who are supposed to sympathise with and appreciate the situation do not engender any commitment on the part of the teachers to the vacation. Consequently

120 Journal of Science and Technology, Vol. 28, No. 2, August, 2008 
the urge to do some extra work becomes imperative.

Overburdened with physical and mental fatigue, the teacher finds the over-populated class a great source of strain. An ideal class of 35 is now doubled for the average teacher when the corresponding rewards are lacking. The teacher's plight in this scenario becomes complete when he contemplates his powerlessness, the loss of his major coping resources. This involves the abandonment of the traditional way of solving the problem of 'problematic children'. Society has now become so civilized that there is currently a different notion of justice - what is considered a reasonable punishment. Caning is now a thing of the past. This is where the family role becomes crucial. Unfortunately, there are many broken homes to contend with. It is at this stage that financial troubles add their share and compound the problems. Lack of wholesome family education crowned by the lack of good exemplary life by adults in the community for the youth to emulate accelerates the disturbing motion already in process.

\section{Social-economic pressures $\&$ anomic condi- tions}

A combination of the above factors have over the years produced socio-economic pressures and created a monstrous and socially defective environment which has tremendously undermined the structure of our value system.

- The variables that constitute these socioeconomic pressures are:

- The pressure on the family to make ends meet (economic survival), leading to graft and corrupt conduct in the body politic,

- The pressures of an emerging affluent society where wealth takes centre stage at the expense of morality,

- The frightening diminishing of the society's value system,

- The overly powerful influence of the information and communication super highway leading to the so-called Global Village, which has a dominant influence on the morals of today's children,

- The debilitating poverty compounded by globalization and the world economic order

- Lack of visionary, goal-oriented and resultdriven national leadership as a result of disruptive political growth and development of the country.

It is difficult to appreciate the sources of Socioeconomic pressures on individuals without reference to Durkheim's concept of 'Anomie'. Anomie in Sociological jargon represents any state of 'normlessness', 'lack of rules' or 'deregulation'. It is an inevitable facticity in the course of the development of Societies that is traceable to two main reasons.

The first, according to Durkheim (1897), is associated with the development of Industrial Societies; and the second to the role and the importance the Economy assumes over all other institutions in society. The attendant consequences have far reaching implications on the lives of individuals and society as a whole.

There are three (3) consequences that follow from the rise of Industrial Society: Firstly, it promotes individualism; Secondly, it leads to Social Framengmentation and Thirdly, the weakening of social bonds tying the individual to society.

On the economic front, the quest for survival becomes the major pre-occupation of man. Coping with Social Reality becomes, for many individuals, particularly from the lower strata of society 'the end justifies the means'. Honesty as a virtue becomes an unattainable commodity and for some, suicide becomes a preferred alternative to life.

There is under such circumstances also a rise in the commission of crimes against persons and property. These are described as Crimes Committed by the working classes against the working classes. Ghana was highly anomic in 1983.

Anomic conditions lead to a disorganized neighbourhood which in turn become antecedent 
conditions which, firstly, breed contradictions between personal troubles and public issues and subsequently breeding grounds for the emergence of distinct delinquent subcultures like criminal and conflict subcultures (Cloward and Ohlin 1961).

\section{Family problems and failure of home life}

In his classic study of the social survey of Second/Takoradi between October 1947 and April, 1948 , when the country was under colonial rule. Busia (1951) concluded, 'Juvenile delinquency is primarily due to failure of home life'.

From the analysis of the case histories of the delinquents, Busia identified the factors contributing to delinquency to be varied including:

- Housing difficulties,

- Overcrowding,

- Underfeeding,

- Poverty,

- The absence of recreational facilities,

- Discontinuance of schooling,

- The disintegration of the family system,

- Conflict or dichotomy of cultural standards, and the tempting environment of the town. But broken homes and defective parental control were the predominant causes.

Many of the family problems described above are problems that predominantly affect the working classes. The Sociological truism is that defective parental control and socio-economic pressures are predominantly but not exclusively working class phenomena. An interesting observation made by Assimeng (1981) and Asamoah (2007) is about the emergence of incipient stages of class conciousness in Ghana.

According to Assimeng -

'Social classes, in the sense of segments of the population who enjoy similar economic circumstances and life chances, and who wish to improve upon their position and to maintain a distance from those who do not belong to such positions, clearly exist in Ghana; one only has to visit Nima, Sukula, Bukom on the one hand, and the Kanda and the Osu Ringway estates, and the airport residential area, on the other, to realize the relationship between class structure and patterns of accommodation in Accra'.

Asamoah also discusses in detail the general economic background of the class situation in Ghana. According to Asamoah, the proletariat class comprises

"all workers skilled and unskilled' and 'their social conditions are nothing to write home about. Average monthly wages are rather low and could scarcely sustain the earners for two weeks. Most of the workers live in semi-ghetto and crude shanty settlements (especially in the Urban Centers where the generality of urban social infrastructure leaves much to be desired'.

The working classes are most vulnerable for numerous reasons. Largely, it has to do with their status in life. In terms of life chances they are the most disadvantaged. Their lack of education is a major handicap. Education broadens the mental horizon of the individual. Consequently one's location, perception, understanding, interpretation and appreciation of the world are dependent on one's level of education. Lack of education, therefore, breeds ignorance. Unfortunately, ignorance is no excuse!

In terms of fruitful interaction and communication within the family, it is the working class that experiences and suffer for its lack of performances. In short, the poor and the working classes lack the freedom and autonomy so prized in our society. They are trapped by their surroundings, living in run-down crime-ridden neighbourhoods that they cannot afford to leave. They are constantly confronted with things they desire but have little chance of owning.

In contrast the world of the wealthy classes i.e. Middle and Upper classes offers the best that most poor people have not even heard of. Wealth provides power, freedom and the ability to direct one's own fate. The advantages of education and wealth are many. This is not in anyway to sug-

122 Journal of Science and Technology, Vol. 28, No. 2, August, 2008 
gest that the middle and upper classes do not encounter problems. A sizable proportion of the affluent members of our society do not have quality time for their children.

Failure of home life is no respecter of persons. Many children from the well-to-do family abuse drugs.

These differences have very serious and far reaching implications not only for effective upbringing of their children but also for the entire society.

Relating the above framework to the current socio-economic environment of our country, we could decipher a strong linkage. The anomic conditions, socially disorganized neighbourhood, family problems and class differences are the consequences of ruthless industrial economy, which in the developed countries has advanced to a knowledge economy.

\section{Failed political leadership}

It would be an understatement to stipulate that since Ghana's independence its political leadership has been plagued by monumental failure and disappointments. We have had to endure and contend with problems of political instability. From independence 1957 to the present $4^{\text {th }}$ Republic we have gone through the following political regimes. C.P.P under Nkrumah, N.L.C. under Busia, S.M.C.I, under Acheampong, S.M.C II under Akuffo, A.F.R.C. underRawlings, P.N.P under Liman, P.N.D.C. under Rawlings, N.D.C. again under Rawlings and finally N.P.P. under President Kuffour. The results of our political instability have immeasurably contributed to the crisis of indiscipline that is confronting this country. Our political leaders have been incapacitated in dealing with the monstrous problems confronting Ghana.

The late Dr. Kwame Nkrumah a 'dye-in-thewool' socialist trumpeted his socialist ideals. Unfortunately, his close associates in the political establishment did not exhibit such passion for socialism and were amassing wealth with abandon leading to the fame of his Dawn Broadcast. These palpable contradictions among others contributed to his overthrow in 1966. Boahen (1964) captures the picture vividly when he describes Nkrumah's dilemma in the following manner

'The active practice of socialism proved to be Nkrumah's first tactical mistake for the majority of his own cabinet members, his own party officials, his own member of parliament and most of the rank and file of his party were opposed to this socialist reconstruction of society. The result was that from 1960 onwards, the party itself was split into two, the anti-socialist group led by people like krobo Edusei, W.A. Wiafe, C.K.K. Baah and K.A. Gbedemah and the socialist group led by Kofi Baako and Tawiah Adamafio from the socialist group, which was clearly in the minority,; was further divided into the scientific socialists, such as Kofi Batsa, S.G. Ikoku, Heyman, Tawiah Adamafio, K. Amoako-Atta and T.D. Baffoe who were opposed to the adaptation. Thus throughout the second period, the CPP was split party and conflicts between the socialist and non-socialists or capitalists and between the scientific and African socialists and non-socialist or capitalists and between the scientific and African socialist raged with increasing intensity and bitterness and Nkrumah had to spend a great deal of time playing one group against the other and trying to maintain party unity.'

In fact Nkumah's role started the degradation in the value system of the country, which at that time was evolving at the dawn of the country's independence and triggered the political indiscipline in the body politic. The subsequent political leadership have been incapacitated in dealing with this monstrosity, which has become the 'sword of Damocles' hanging on the neck of Ghana. The Military adventurists did not live up to expectation. The dictatorship that their rule unleashed on the country exacerbated the degradation in the value system through their blatant disregard of national norms, conventions and customs. 
Another contributory factor to indiscipline in the political arena has been the lack of a robust value-driven political leadership. As a result of this the country is faced with a crisis of identity of a National Value System. This has led to a situation where immorality is accepted as morality. Misconduct, dishonesty and double standards in public life are not frowned upon but generally accommodated and accepted.

\section{Suggested solutions}

Every member of society has a role to play. The starting point must be from the home. The role of parents is crucial because they constitute the 'significant ones' for the individual. Parents must exhibit special concern and interest in the upbringing of their wards. This commitment must be total. For instance, mere provision of basic needs is not enough. It must be matched by persistent dialogue to identify the problems, fears, anxieties etc, of the minor.

With the educational system, a radical restructuring of the academic curriculum is essential. It is unfortunate that the academic curriculum of most developing countries, Ghana not excepted, follows the apron strings of the former political over lords. Restructuring must be in line with the management and exploitation of the economic base of the country to suit the changing trends in industry - primary, Secondary and Tertiary. A dynamic relationship must be established between the humanities, the sciences and the world of work. Students must be selected and trained to fill opportunities that would avail themselves in the world of work rather than absorbing students regardless of their professional inclination who make the grade for University admission.

The Junior High School (J.H.S.) system despite its teething problems is indeed a step in the right direction. The former educational system did not provide adequate avenues for pupils who did not have aptitude for academic work. There is, however, the need to institute course and career counselling for students before they enter the
Senior Secondary Schools, the Polytechnics and Universities so as to eliminate frustration often experienced by students preparing to pursue job. In both cases, aspiring candidates must be adequately informed as to the job opportunities that may be available and the changes that are likely to develop. Sex education must be included in the school curriculum. The hostile attitude of some conservative adults against the discussion and discrimination of sex education must be disabused because most of the unplanned pregnancy is the result of ignorance.

The other important agencies, i.e. the 'generalized others' are the community organizations, namely, religious, institutions and the mass media. Their role as definers, interpreters and enforcers of social values is crucial. What is required is an integrated approach. The mass literacy campaign already started is a step in the right direction. The ministries of Health, Education, Information, Mobilization, Social Welfare and the Churches must integrate public awareness of the consequences of unplanned childbirth and drug abuse. In fact teachers, religious leaders and the community have a moral duty to discharge. It is more of a conscious and integrated approach to provide the tools to combat liberal indulgence in drugs and sex. Most importantly it must be backed by good exemplary lives by adults for the youth to emulate.

Success in life must not be measured by the achievement of material acquisition and academic laurels alone. Moral uprightness leads to the achievement of inner peace and this must be inherited through self-control which is needed in every youth has been endowed with a useful potential. The youth must be made to realize this. It is important to have leaders who can effectively preach God's word, but it is even more important to have those who live out God's word and be examples for others to follow. Community organizations could be a focal point for the mobilization of the youth in recreational activities such as boys scouting, Red Cross, Boys and Girls brigade etc, which will occupy the youth and direct

124 Journal of Science and Technology, Vol. 28, No. 2, August, 2008 
their energies towards a better commercial development.

\section{CONCLUSION}

In the light of the above analysis it is clear that individuals in any given society have personal troubles, and it is these personal troubles that eventually become public issues. Many families are unable to fulfil these important obligations including quality moral education because they are handicapped in one way or the other, for instance, poor finances or ignorance. The state must in this respect recognize the plight of some working class families. Inequalities in wealth, income and education must be appreciated. Parents' authority and influences over their children cannot be complete until there is a corresponding qualitative improvement in their quality of life. Most often the state, for good reason, succeeds in diverting attention from real issues. Until the structural sources of contradictions are addressed as suggested above the spate of indiscipline will persist for a long time.

The bold and admirable campaign initiative launched by the Vice President years ago seems if not completely, to be dying. Fortunately, the Ministry of Information and National Orientation on Thursday, August 2007 launched what it termed the five pillars of national orientation which are expected to serve as reference points for charting new paths for National Development. The five (5) pillars are:

i) Proud to be a Ghanaian

ii) Patriotism and a spirit of Ghana first

iii) A Can-Do-It Attitude

iv) Productivity and Accountability

v) Dedication and Discipline

We all need to encourage the Ministry of Information and National Orientation to sustain this salutary initiative. It is imperative to strengthen both political and moral leadership at all levels to start building consensus on what constitutes our national values, which as a nation could be developed to regulate our behaviour and con- duct. This is the challenge we face as a nation, and we must all rise to the occasion.

\section{REFERENCES}

Asamoa, A.K. (2007). Classes and Tribalism in Ghana; third Edition Woel, Publishing Services Accra, Ghana. Pp. 30 - 58.

Assimeng, M. (1999). Social Structure of Ghana, Second Edition, Ghana Publishing corporation, Accra, Ghana. Pp 235 - 270.

Boahen, A. (2000). Evolution and change in the Nineteenth and twentieth century. Sankofa Educational Publishers Ltd. Ghana. Pp 206 221

Busia, K.A. (1951). Report on a social survey of Secondi/Takoradi - Crown Agents for colonies. Pp. $84-118$.

Cloward, R. and Lloyd, O. (1961). Delinquency and opportunity. London, collier Macmillan. Pp 161-186.

Durkheim, E. (1897). Suicide. The Free Press, New York

Mensah, A. (1973). Family Background and Educational Opportunities in Ghana. A critical look at the Secondary School Mechanism - The Common Entrance examination Ghana University Press. Pp. 134 - 187

Nkrumah, K. (1962). Towards colonial freedom Heineman. London. Pp $1-43$

Nukunya, G.K. (2005). Tradition and Change in Ghana, Accra, Ghana. University Press. Pp 3 - pp 107 -241.

Oliver, R. and Atmore, A. (1996). Africa since 1800 Cambridge University Press. Pp 100 124.

Parsons, T. (1951). The social System. Free Press New York. Pp $26-36$. 